\title{
HYDROGEOLOGICAL FUNCTIONING OF A KARST AQUIFER DEDUCED FROM HYDROCHEMICAL COMPONENTS AND NATURAL ORGANIC TRACERS PRESENT IN SPRING WATERS. THE CASE OF YEDRA SPRING (SOUTHERN SPAIN)
}

\author{
RAZLAGA HIDROGEOLOŠKEGA DELOVANJA KRAŠKEGA \\ VODONOSNIKA NA PODLAGI HIDROKEMIČNIH ELEMENTOV \\ IN NARAVNIH ORGANSKIH SLEDIL PRISOTNIH V IZVIRSKI \\ VODI. PRIMER IZVIRA YEDRA (JUŽNA ŠPANIJA)
}

\author{
Matías MUDARRA ${ }^{1} \&$ Bartolomé ANDREO ${ }^{1}$
}

\begin{abstract}
UDC 556.34.04(460-13)

Matías Mudarra \& Bartolomé Andreo: Hydrogeological functioning of a karst aquifer deduced from hydrochemical components and natural organic tracers present in spring waters. The case of Yedra Spring (Southern Spain)

The major chemical parameters, TOC and natural fluorescence of Yedra spring, Malaga province, southern Spain were monitored from April 2008 to March 2009. The electrical conductivity and the concentrations of most major ions decreased following recharge periods. The TOC and $\mathrm{NO}_{3}^{-}$, representing tracers from the soil that infiltrate through the unsaturated zone, were found to vary inversely with the $\mathrm{Mg}^{2+}$ content, which is a natural indicator of groundwater residence time. Furthermore, a strong, direct relation was found between TOC and the natural fluorescence associated with humic and fulvic acids. Both parameters respond similarly to rainfall events, exhibiting significant increases during recharge followed by reductions during recession. This relation means that TOC mainly originates from organic acids. The results document rapid infiltration processes with a lag of less than one day following rainfall, which is typical of a karst aquifer with conduit flow, rapid drainage and limited natural regulation. The combined use of conventional hydrochemical parameters and natural organic tracers facilitates aquifer characterization and validates the vulnerability to contamination.

Keywords: hydrochemical response, Total Organic Carbon, natural fluorescence, nitrate, Southern Spain.
\end{abstract}

Povzetek

UDK 556.34.04(460-13)

Matías Mudarra \& Bartolomé Andreo: Razlaga hidrogeološkega delovanja kraškega vodonosnika na podlagi hidrokemičnih elementov in naravnih organskih sledil prisotnih v izvirski vodi. Primer izvira Yedra (Južna Španija)

Poglavitni kemični parametri, TOC in naravna fluorescenca izvira Yedra v provinci Malaga, v južni Španiji, so bili vzorčevani in beleženi od aprila 2008 do marca 2009. Električna prevodnost in koncentracije večih glavnih ionov so upadle po dežju. TOC in $\mathrm{NO}_{3}^{-}$, ki predstavljata naravni sledili iz prsti in prenikata skozi nezasičeno cono, sta se pojavili inverzno s pojavom $\mathrm{Mg}^{2+}$, ki je naravni kazalec zadrževalnega časa podzemne vode. Izrazita neposredna povezava je bila ugotovljena med TOC in naravno fluorescenco, povezano $\mathrm{z}$ huminskimi in fulvičnimi kislinami. Oba parametra se odzivata podobno na deževne dogodke in kažeta značilne poraste vrednosti ob deževnih obdobjih, ki jim sledi upad teh viškov v času upadanja vodostajev. Takšno nihanje TOC vrednosti nakazuje na njegov izvor v organskih kislinah. Rezultati kažejo na hitre infiltracijske procese s časovnim zamikom manj kot en dan po deževju, kar je značilno za kraške vodonosnike s kanalskim pretakanjem, hitrim odvodnjavanjem ter omejeno naravno regulacijo. Skupna uporaba konvencionalnih hidrokemičnih parametrov in naravnih organskih sledil je omogočila opredelitev značilnosti vodonosnika ter potrdila njegovo ranljivost na onesnaženje. Ključne besede: hidrokemični odziv, skupni organski ogljik, naravna fluorescenca, nitrati, južna Španija.

\footnotetext{
${ }^{1}$ Centre of Hydrogeology and Department of Geology of University of Malaga (CEHIUMA), Málaga, Spain, e-mail:mmudarra@uma.es, andreo@uma.es
}

Received/Prejeto: 4.12.2009 


\section{INTRODUCTION}

Studies of karst systems have traditionally focused on analysing the natural responses of springs to recharge events (Goldscheider \& Drew 2007). These responses include variations in temperature (Andrieux 1978; Genthon et al. 2005), chemical composition (Bakalowicz 1979; Mudry 1987; Hess \& White 1993), and hydrodynamic parameters (Mangin 1975; Bonacci 1993). The individual or combined use of these responses provide insights on the hydrogeologic characteristics and functioning of karst aquifers.

In this respect, the joint use of natural hydrogeochemical tracers (TOC, $\mathrm{NO}_{3}^{-}$, natural fluorescence) and major hydrochemical components such as $\mathrm{Mg}^{2+}$ is useful for characterizing infiltration processes, the water transit times, flow conditions and, above all, the degree of participation of the saturated and unsaturated zones in the functioning of karst systems.

soil (humic and fulvic acids, and protein organic matter) which, in turn, form part of TOC, and consequently could be interesting indicators of rapid infiltration (Baker et al. 1997, 1999; Blondel 2008; Cruz Jr. et al. 2005). Several authors have investigated karst systems by continuous monitoring of organic carbon (TOC), turbidity, particle-size distribution, faecal bacteria, nitrate and other parameters (Pronk et al. 2006, 2009; Mahler \& Garner 2009). These authors consider that natural fluorescence correlates with the concentration of dissolved organic matter, but the relationship varies between catchments depending on organic matter character and the proportion of fluorescent organic matter (Cumberland \& Baker 2007).

Another aspect is that the $\mathrm{Mg}^{2+}$ content, which is a major ion, informs on the residence time of the water in the aquifer, particularly in the saturated zone $(\mathrm{Ba}-$ tiot et al. 2003a; Emblanch

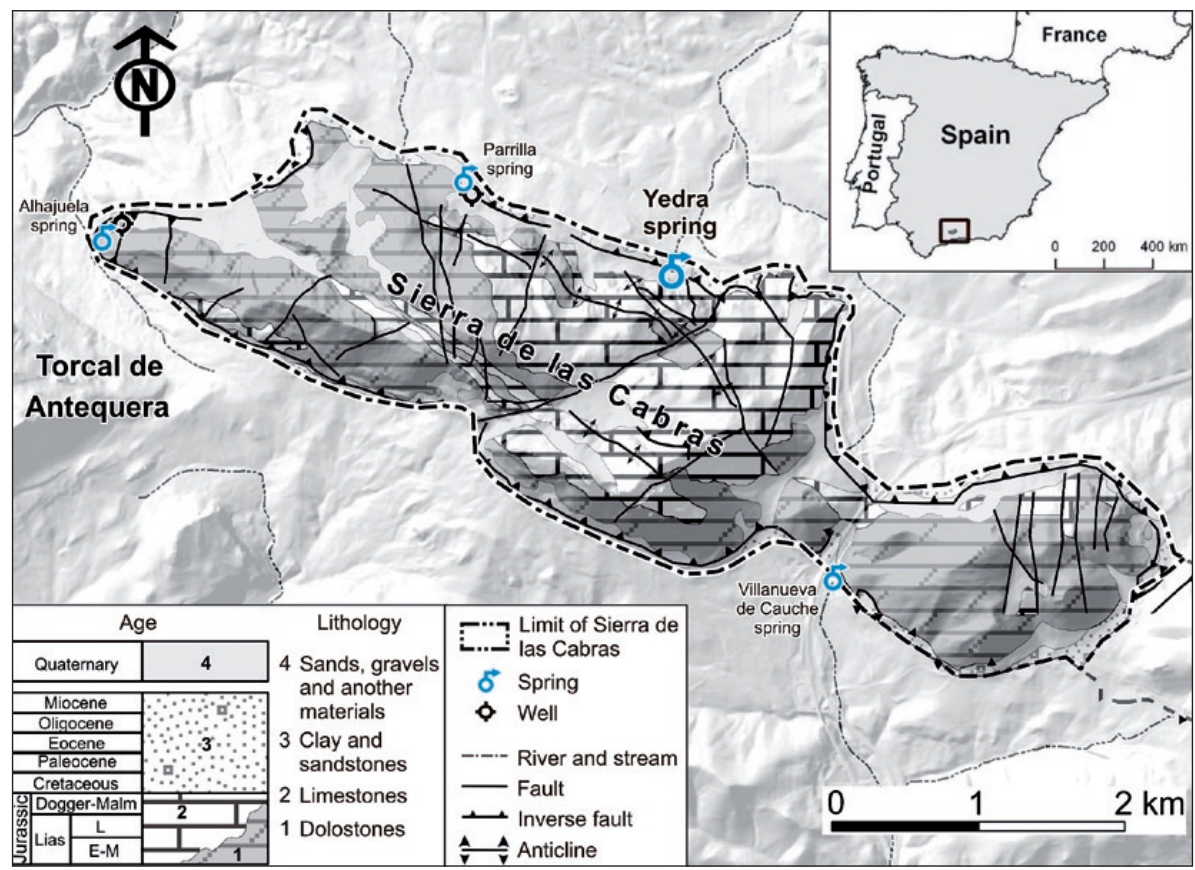

Fig. 1: Geographic location and geological-hydrogeological sketch of the Sierra de las Cabras experimental area, showing the situation of the Yedra spring. et al. 1998, 2003), although its concentration also depends on other parameters such as the chemical and mineralogical purity of the limestone and the presence of dolomite.

From April 2008 to March 2009, the hydrochemical and hydrodynamic responses of Yedra spring in Malaga province, southern Spain (Fig. 1) were monitored in order to determine the relative importance of the saturated and the unsaturated zones in the hydrogeologic functioning, to characterize the karst aquifer, to determine its vulnerability to contamination, and to improve its management. This aquifer is naturally drained toward the superficial streams and serves as a

Certain organic tracers originate in the soil covering the epikarst. Of these, Total Organic Carbon (TOC) is the most commonly used because, when there is no human-originated contamination or flows from the surface, it serves as an indicator of rapid infiltration (Batiot et al. 2003a, b; Emblanch et al. 1998, 2003). Moreover, the natural fluorescence of dissolved organic matter is related to certain chemical compounds present in the resource for irrigation and drinking water.

The aim of the present study is to contribute to characterize infiltration processes and to determine the hydrogeologic functioning of the carbonate aquifer examined, by means of natural hydrochemical tracers and the major chemical components in the spring water. 


\section{GENERAL CHARACTERISTICS OF THE STUDY AREA}

Yedra spring is the main drainage point for the carbonate aquifer of Sierra de Las Cabras. This aquifer has a surface area of approximately $10.5 \mathrm{~km}^{2}$ and it is located in the province of Malaga in southern Spain. The spring is part of a larger karst aquifer system known as Sierra de las Cabras - Camarolos - San Jorge $\left(70 \mathrm{~km}^{2}\right)$. The landscape is very rugged, with altitudes ranging from 800 to $1,300 \mathrm{~m}$ asl. The prevailing climate is of temperate Mediterranean type, with a mean annual temperature of $16^{\circ} \mathrm{C}$. Mean annual precipitation is $700 \mathrm{~mm}$ but is characterized by large annual and interannual variations.

From a geological standpoint, Sierra de Las Cabras is located in the Betic Cordillera, and is underlain by oolitic limestones and Jurassic dolostones, which are bounded, at the base, by Upper Triassic clays mixed with evaporates. To the north and south, the area is bordered by flysch-type clays (Fig. 1). The geologic structure includes anticlinal folds oriented approximately E-W that are cut by faults.

The karst features in Sierra de Las Cabras aquifer is relatively well developed at the surface of the carbonate outcrops, mainly in the Jurassic oolitic limestones that occur at the highest altitudes, where karrenfield can be observed. Recharge takes place by the direct infiltration of rainfall, and the aquifer discharges through several springs along the northern border, the most important being Yedra spring which was selected for the present study. Previous researches of this area and the associated aquifer include Pulido Bosch \& Cerón (1991), Marín et al. (2007), Mudarra \& Andreo (2007) and Mudarra et al. (2008).

\section{METHODOLOGY}

From April 2008 to March 2009, sampling was performed twice weekly, daily during some periods of high water conditions, and twice monthly during periods of flow recession. Concurrently with the sampling programme, the temperature and electrical conductivity of the water were measured, using portable equipment (to a precision of $\pm 0.1^{\circ} \mathrm{C}$ and $\pm 1 \mu \mathrm{S} / \mathrm{cm}$ respectively).

The hydrochemical parameters were analyzed at the Laboratory of Hydrogeology of the University of Málaga. Total Alkalinity Content (TAC) was determined by volumetry with $\mathrm{H}_{2} \mathrm{SO}_{4} 0.02 \mathrm{~N}$ to $\mathrm{pH} 4.45$. Analyses of major ions $\left(\mathrm{Ca}^{2+}, \mathrm{Mg}^{2+}, \mathrm{Na}^{+}, \mathrm{Cl}^{-}, \mathrm{SO}_{4}^{2-}, \mathrm{NO}_{3}^{-}\right.$, ) were performed by ionic chromatography. TOC was measured using a carbon analyzer (Shimadzu, V-TOC).

Natural fluorescence was measured with a spectrofluorimeter (Perkin-Elmer, LS-55). WinLab software was used to obtain the excitation-emission matrices (EEM) corresponding to each of the samples. In every case, the excitation $\left(\lambda_{\mathrm{ex}}\right)$ wavelength ranged from $200 \mathrm{~nm}$ to 350 $\mathrm{nm}$ with a $5 \mathrm{~nm}$ slit, while the emission $\left(\lambda_{\mathrm{em}}\right)$ wavelengths varied from 250 to $550 \mathrm{~nm}$. The fluorescence values recorded for EEM refer to Fluorescence Intensity Units (FIU) measured in Uf.nm² (Baker et al. 1997; Blondel 2008). We only took into account the highest values for fluorescence intensity visible in the EEM, of which only two maximum values appear in every sample, corresponding to the organic chemical substances considered in this study (upper and lower peaks). The upper fluorescence peak appears between 300-340 nm excitation and
400-440 emission, while the lower one was identified between 225-245 nm excitation and 400-450 nm emission.

The hydrochemical data were analyzed using different procedures. The electrical conductivity frequency distributions (CFD) of the spring water inform on the variability of the mineralization and on the chemical composition of the water (Bakalowicz 1979). If the curve presents a unimodal shape, with a small range of variation, this indicates a low degree of development of functional karstification. If, on the other hand, there is no clearly defined mode (i.e., we are considering a multimodal situation), then there exists a high degree of functional karstification in the aquifer drained by the spring (Bakalowicz 1979; Mudry 1987). The temporal evolution of the chemical concentrations quantified the lag between rainfall and the hydrochemical response. The magnitude of the dilutions provided a means to estimate the degree of functional karstification of the aquifer.

Particular account was taken of the contents of $\mathrm{NO}_{3}^{-}$, $\mathrm{Mg}^{2+}$ and TOC, and the natural florescence of the water. Correlation diagrams of these constituents quantify their interrelationships. Thus, $\mathrm{NO}_{3}^{-}$and TOC contents and natural fluorescence are derived from the aquifer surface (soil) and they are indicators of the transit time of the infiltration through the unsaturated zone, while the $\mathrm{Mg}^{2+}$ content reflects slow dissolution of dolostones (Appelo \& Postma 1996; Langmuir 1997). Thus the $\mathrm{Mg}^{2+}$ content provides an indicator of the residence time of the water within the aquifer (Batiot et al. 2003a; Emblanch et al. 1998, 2003), 
especially in the saturated zone where dolostones are predominant in the pilot site, because they are stratigraphically beneath the limestones (Fig. 1). Nevertheless, it also depends on other parameters, such as the chemical and mineralogical purity of the limestone and the presence of dolomite.

Principal Component Analysis (PCA) is a multivariate statistical technique that is used for grouping variables and water types that may be associated with the same hydrodynamic conditions or with a common origin. Numerous studies have used PCA to interpret, group or classify hydrochemical data (Bakalowicz 1977; Mudry 1987; Reisenhofer et al. 1998; Karimi et al. 2005).

\section{RESULTS AND DISCUSSION}

\section{STATISTICAL PARAMETERS AND ELECTRICAL CONDUCTIVITY FREQUENCY DISTRIBUTIONS}

Tab. 1 presents relevant statistical parameters concerning the chemical composition of the water drained by Yedra spring. This spring discharges calcium bicarbonate water with a low electrical conductivity of $280-369 \mu \mathrm{S} / \mathrm{cm}$, which highest values corresponding to low flows. The frequency distribution of the electrical conductivity (Fig. 2) is multimodal with 4 distinct peaks (P1, P2, P3, $\mathrm{P} 4)$. The highest peak (P2) represents up to $16 \%$ of the total accumulated frequency. The range of variation is from $280 \mu \mathrm{S} / \mathrm{cm}$, during periods of dilution (high water conditions), to $370 \mu \mathrm{S} / \mathrm{cm}$ during periods of low water, using electrical conductivity classes of $5 \mu \mathrm{S} / \mathrm{cm}$.

The statistical parameters, particularly the values of the coefficient of variation of all the hydrochemical parameters (Tab. 1), indicate a high level of hydrochemical variability, and suggest that karst conduits drain the aquifer. The frequency distribution of the electrical conductivity (Fig. 2) is consistent with the presence of karst conduits according to Bakalowicz (1977).

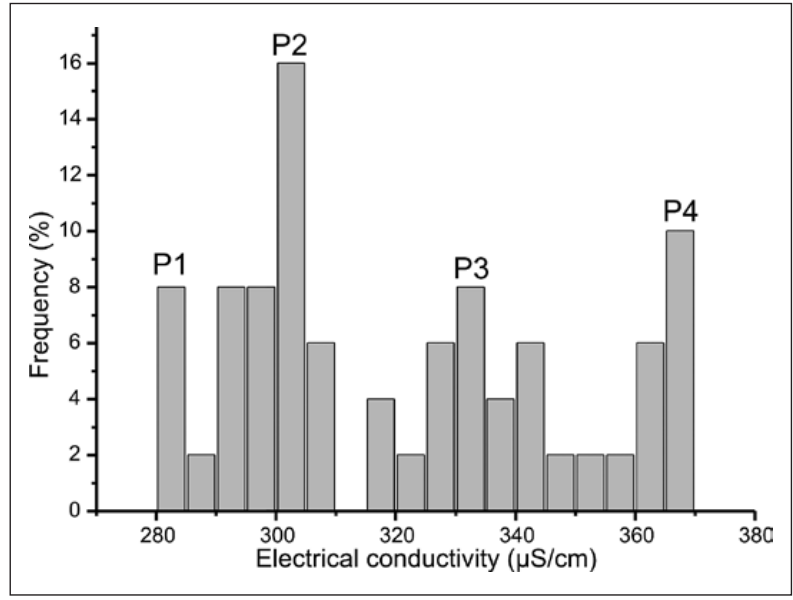

Fig. 2: The electrical conductivity frequency distributions defined by periodic measurements of Yedra spring.

Tab. 1: Statistical parameters of the water samples analyzed from the Yedra spring during the period from April 2008 to March 2009. $(n)$ number of samples, $(\sigma)$ standard deviation, $(v)$ coefficient of variation.

\begin{tabular}{|c|ccccccc|}
\hline Yedra spring & E.C. $(\mu \mathrm{S} / \mathrm{cm})$ & $\mathrm{T}\left({ }^{\circ} \mathrm{C}\right)$ & $\mathrm{Q}(\mathrm{L} / \mathrm{s})$ & T.A.C. $(\mathrm{mg} / \mathrm{L})$ & $\mathrm{Ca}(\mathrm{mg} / \mathrm{L})$ & Up.P.fluor. (Uf.nm $\left.{ }^{2}\right)$ & T.O.C. $(\mathrm{mg} / \mathrm{L})$ \\
\hline $\mathrm{n}$ & 50 & 50 & 49 & 49 & 49 & 49 & 49 \\
mean & 321 & 14.0 & 22.71 & 187.24 & 59.67 & 127.87 & 0.40 \\
$\sigma$ & 27.8 & 1.0 & 23.6 & 18.04 & 2.46 & 47.93 & 0.16 \\
$\mathrm{~V}(\%)$ & $8.66 \%$ & $7.18 \%$ & $103.92 \%$ & $9.63 \%$ & $4.12 \%$ & $37.48 \%$ & $40.00 \%$ \\
Min & 280 & 12.8 & 1.00 & 152.5 & 53.56 & 67.67 & 0.20 \\
Max & 369 & 16.7 & 100 & 219.6 & 63.30 & 290.59 & 0.80 \\
Range & 89 & 3.9 & 99 & 67.10 & 9.74 & 222.92 & 0.60 \\
& & & & & & \\
ng $(\mathrm{mg} / \mathrm{L})$ & $\mathrm{SO}_{4}(\mathrm{mg} / \mathrm{L})$ & $\mathrm{Cl}(\mathrm{mg} / \mathrm{L})$ & $\mathrm{Na}(\mathrm{mg} / \mathrm{L})$ & $\mathrm{NO} 3(\mathrm{mg} / \mathrm{L})$ & Lo.P.fluor. $\left.(\text { Uf.nm })^{2}\right)$ \\
\hline mean & 49 & 49 & 49 & 49 & 49 & 49 & 66.33 \\
$\sigma$ & 10.23 & 10.43 & 6.35 & 3.27 & 11.43 & 2.26 & 25.44 \\
V $(\%)$ & 3.79 & 4.08 & 0.40 & 0.29 & $8.87 \%$ & $19.77 \%$ & $38.35 \%$ \\
Min & $37.05 \%$ & $39.12 \%$ & $6.30 \%$ & 2.81 & 7.53 & 33.51 \\
Max & 5.59 & 5.68 & 5.36 & 2.81 & 150.52 \\
Range & 16.87 & 18.22 & 7.30 & 3.78 & 17.99 & 117.01 \\
\hline
\end{tabular}




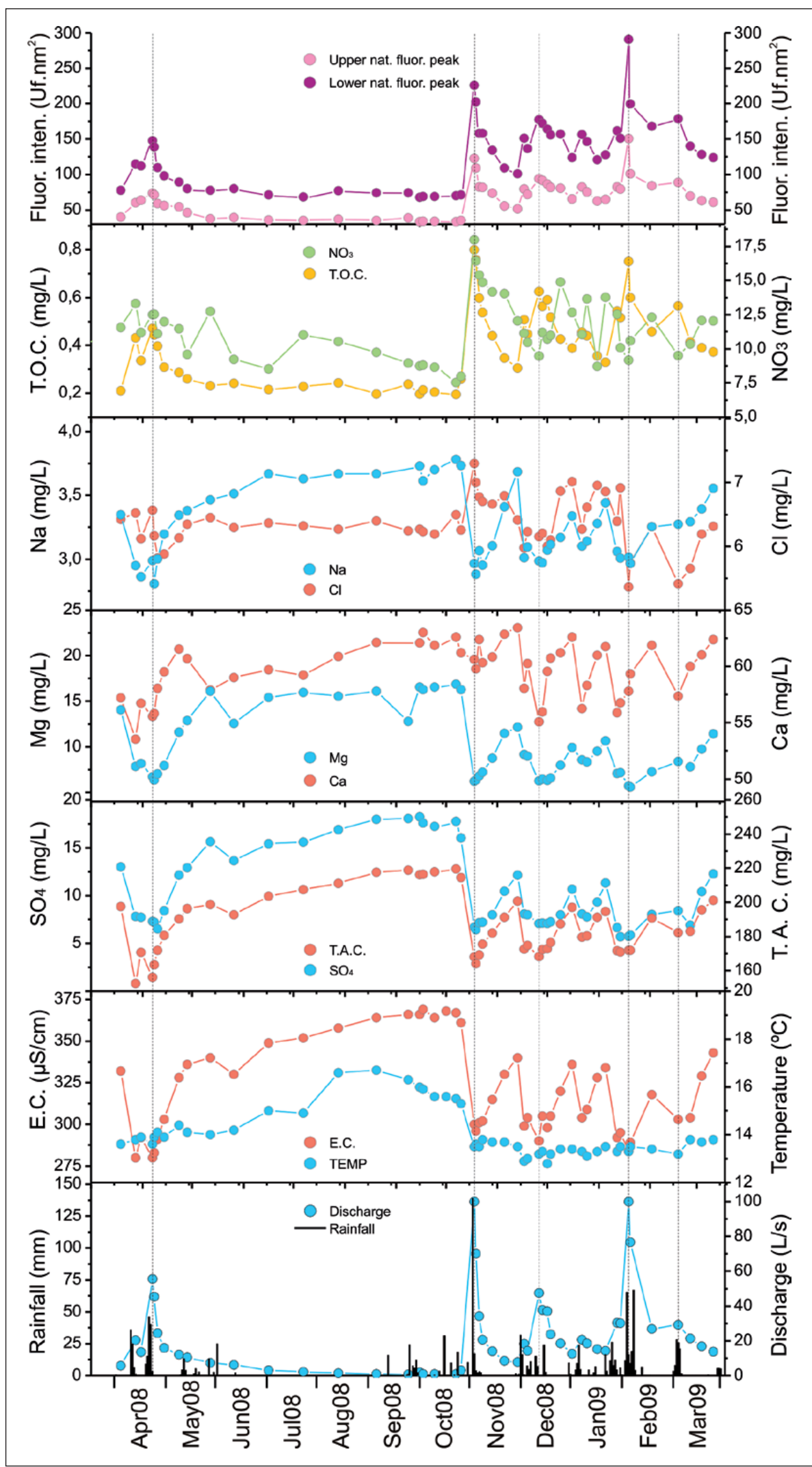

Fig. 3: Temporal evolution of precipitation, discharge rate, water temperature, major chemical components and natural fluorescence peaks of spring water.

\section{TEMPORAL EVOLUTION OF SELECTED \\ PARAMETERS}

Fig. 3 shows the temporal variations of the spring water and precipitation from April 2008 to March 2009. The hydrograph (Fig. 3) reveals sharp increases in flow in response to recharge events, with delays of less than a day (April, November and December 2008, January and February 2009). The hydrochemical parameters show a general seasonal variation. Electrical conductivity, temperature and most chemical components (TAC, $\mathrm{SO}_{4}^{2-}$, $\mathrm{Mg}^{2+}, \mathrm{Ca}^{2+}, \mathrm{Na}^{+}, \mathrm{Cl}^{-}$) have high values during periods of low flow (May-October 2008), and low values during periods of high flow (April, November and December 2008, January and February 2009). Spring temperature is highest during spring and summer. Sharp decreases in electrical conductivity and decreases in the concentrations of most chemical components accompanied each recharge event, as has been observed in previous studies (Pulido Bosch \& Cerón 1991; Mudarra et al. 2008). However, $\mathrm{Ca}^{2+}$ and especially $\mathrm{Cl}^{-} \mathrm{de}-$ creased during the flood of November 2008. This may indicate that the $\mathrm{Cl}^{-}$ion resided in the epikarst and became mobilized with the first rainfall of autumn, but could also result from the dissolution of halite in Triassic evaporites. The $\mathrm{Cl}^{-}$peak of November 2008 can be explained by its evaporative concentration in the soil and epikarst during a protracted dry period (Fig. 3), followed by its rapid 
mobilization following the first significant storm. However $\mathrm{Na}^{+}$content seems to be more retained in the soil by sorption processes.

The contents of TOC and of natural fluorescence vary opposite to those of the major components, with high values coinciding with peak flows. Maximum values occurred during the recharge events of November 2008 and February 2009. The maximum value for $\mathrm{NO}_{3}^{-}$coincided with the high flow of November 2008, but nitrate concentrations decreased during the subsequent high flow periods of December 2008 through March 2009.

The TOC, fluorescence and other components whose concentrations increase during high flow periods appear to be associated with soil, and thus provide natural tracers of infiltration (Batiot et al. 2003a, b; Baker et al. 1997, 1999), although variations in certain constituents could be explained by anthropogenic sources. The high nitrate concentration of November 2008 could be due to the first heavy rainfall, leaching amounts accumulated by biological activity during a long dry period. For this reason, the infiltration water coming from the first heavy rainfall in the autumn usually has a higher content of these components, which decreases progressively as the summer advances. Nevertheless, in all the recharge events there were relative increases in these parameters, as a consequence of the arrival at the spring of water that had infiltrated through the soil, excepting the decreases in $\mathrm{NO}_{3}^{-}$content at the end of 2008 and at the beginning of 2009. The time lag observed for the peaks of the $\mathrm{NO}_{3}^{-}$ was due to the different biogeochemical kinetics of soil nitrogen relative to other organic compounds (Toran \& White 2005; Sánchez-Monedero et al. 2001). The information provided jointly by the majority chemical components and by the natural organic tracers of the water reveals that, for each recharge event, water from the saturated zone mixes with water from the unsaturated zone. The water that has recently infiltrated through the latter zone flows rapidly from the soil and epikarst to the spring, via karst conduits.

\section{COVARIATIONS OF TOC, $\mathrm{NO}_{3}^{-}, \mathrm{Mg}^{2+} \mathrm{AND}$ NATURAL FLUORESCENCE}

Fig. 4 shows the $\mathrm{Mg}^{2+}$ content versus the concentrations of $\mathrm{NO}_{3}^{-}$and TOC of the spring water (Fig. 4A and $\mathrm{B}$ ), and the relation between the peaks of natural fluorescence and the TOC (Fig. 4C). Both TOC and $\mathrm{NO}_{3}^{-}$vary inversely with $\mathrm{Mg}^{2+}$ over a wide range of concentrations (Fig. 4A,B), with the former covariation being strongest.

These diagrams describe the characteristics of the flows through the aquifer. According to Batiot et al. (2003a) and Perrin et al. (2003), the graphs of $\mathrm{NO}_{3}^{-}$and TOC contents which are indicators of the rapid infiltra- tion through the soil and the unsaturated zone, in relation to the $\mathrm{Mg}^{2+}$ content (Figs. $4 \mathrm{~A}$ and $4 \mathrm{~B}$ ), a natural tracer of the residence time of the water in the aquifer (mainly in its saturated zone), reflect the high variability of these natural tracers of the water in Yedra spring. The direct relation observed between the natural fluorescence peaks and the TOC content (Fig, 4C) suggests that this latter parameter is associated with the organic acids that are detected by spectrofluorometry. Accordingly, organic substances can be used as natural tracers of rapid infiltration, as has been done by other authors using parameters such as turbidity, particle-size distribution and faecal bacteria (Pronk et al. 2006, 2009; Mahler \& Garner 2009). The variations in the natural tracers of soil and of the $\mathrm{Mg}^{2+}$ ion in Yedra spring waters indicate that both the unsaturated and the saturated zones participate in the functioning of the system, with the former contribution being magnified during periods of aquifer recharge.

\section{PRINCIPAL COMPONENT ANALYSIS}

A Principal Component Analysis (PCA) was carried out to determine the relation between the different variables and the samples measured (Figs. 5A, B) and provides quantitative assistance in determining the main factors responsible for the total variance. The two main axes of the PCA account for $81 \%$ of the sample variation. Axis I $(68.8 \%)$ is determined by electrical conductivity, temperature, $\mathrm{TAC}, \mathrm{Mg}^{2+}, \mathrm{SO}_{4}^{2-}$ and $\mathrm{Na}^{+}$at the positive extreme, and by TOC, the two natural fluorescence peaks and the discharge at the negative extreme (Fig. 5A). Axis II (12.4\%) mainly addresses $\mathrm{Cl}^{-}$ion at the positive part. The $\mathrm{Ca}^{2+}$ variable was not assigned to either of these two principal factors, but rather is associated with Axis III, which is not described in this paper.

The group near the negative part of Axis I (EC, T, TAC, $\mathrm{Mg}^{2+}, \mathrm{SO}_{4}^{2-}, \mathrm{Na}^{+}$) includes variables associated with karst mineralization, or indicators of long residence time in the aquifer, while the group in the positive part includes the tracers of the infiltration (TOC, natural fluorescence, $\mathrm{NO}_{3}^{-}$), plus the discharge. In contrast, Axis II includes only $\mathrm{Cl}^{-}$, in its positive part, which seems to be a tracer of the epikarst, although it may partly originate in evaporites. Note that $\mathrm{Na}^{+}$does not plot near $\mathrm{Cl}^{-}$, possibly indicating that it is retained by sortion processes in the soil or epikarst and its content comes mainly from small quantity of halite included in the evaporites.

In factorial plane I-II of the statistical units (Fig. 5B), three water groups can be distinguished. Group 1 is constituted entirely of water samples located in the positive part of Axis I, and presents a wide range of variation, both negative and positive, relative to Axis II. This group was 


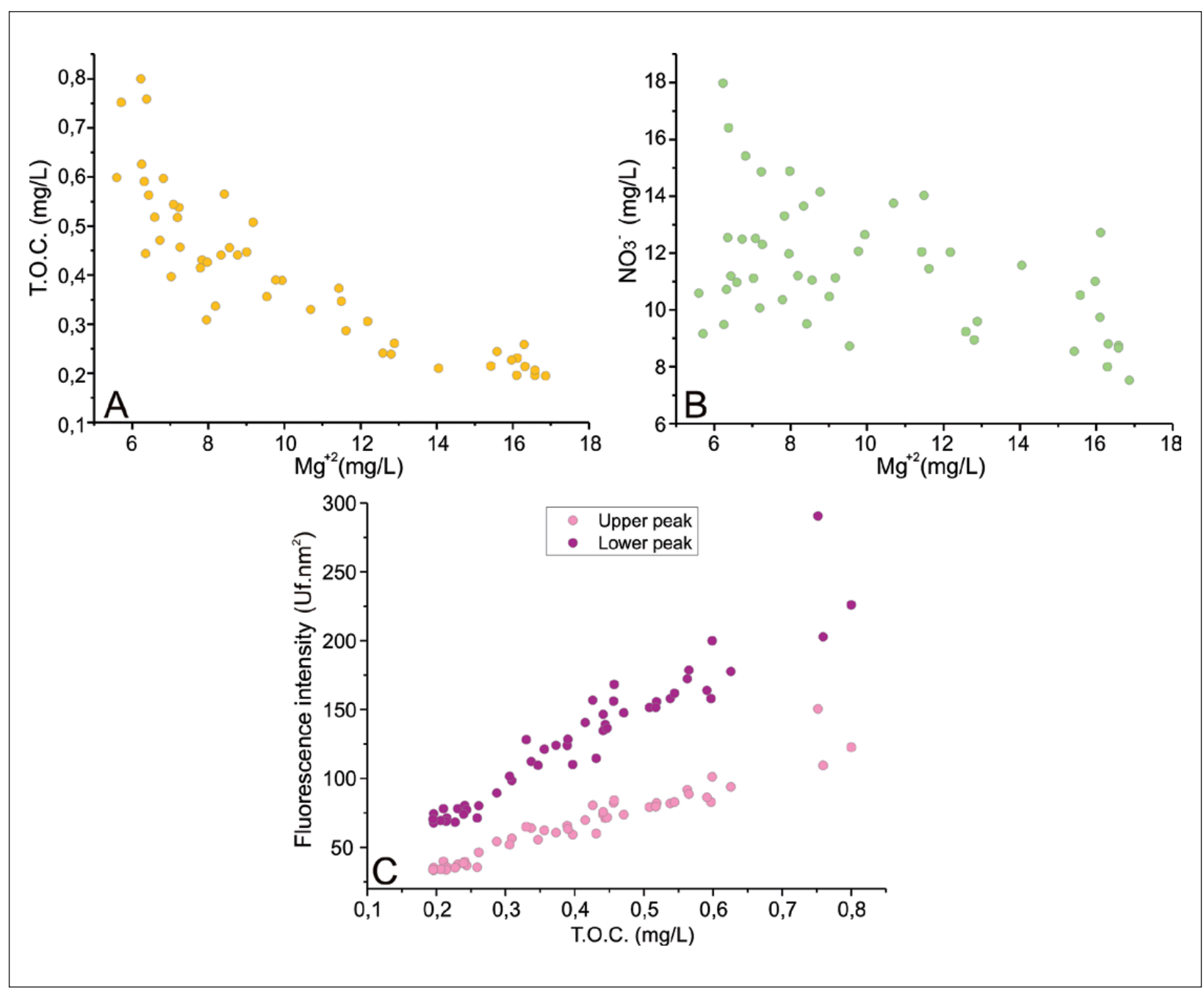

Fig. 4: Diagrams of the TOC (A) and $\mathrm{NO}_{3}^{-}(B)$ versus the $\mathrm{Mg}^{2+}$ content. Plot C shows relation of natural fluorescence to TOC.

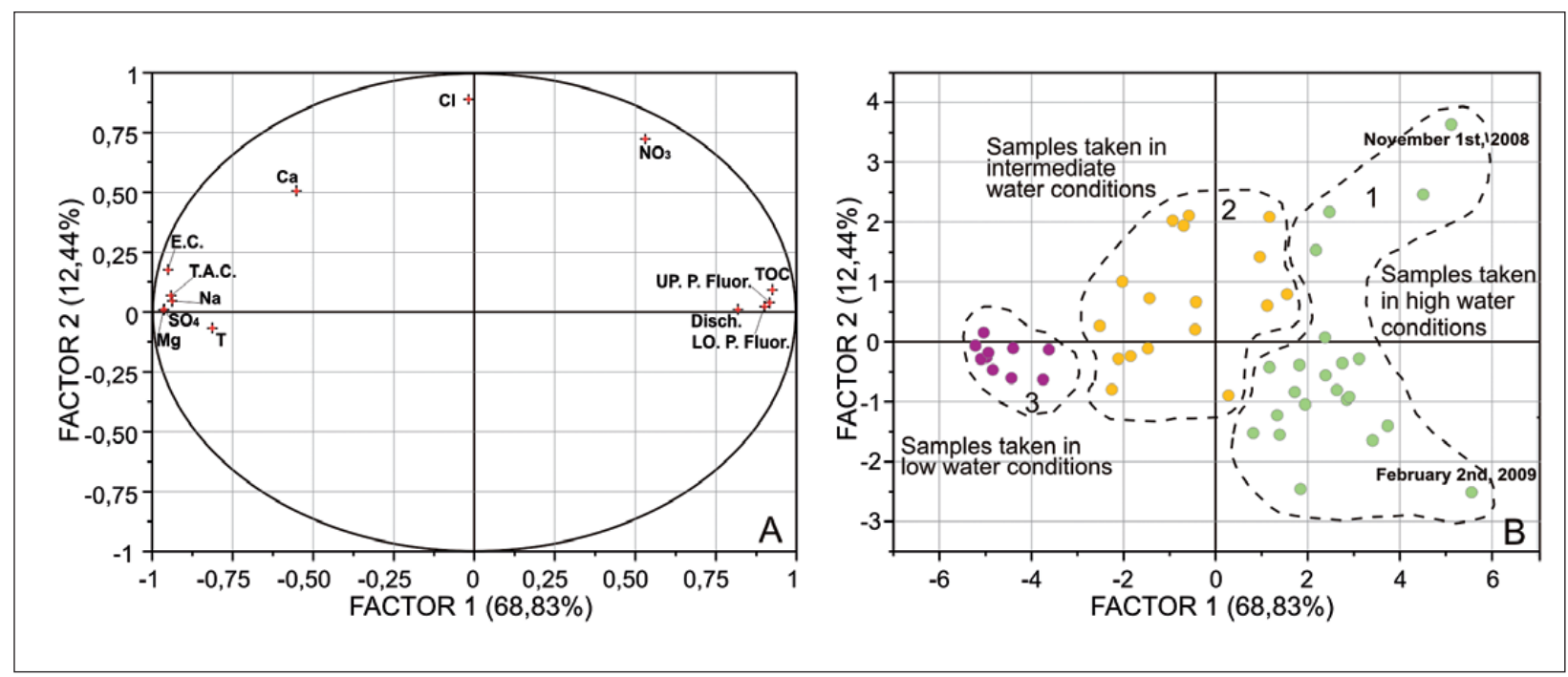

Fig. 5: Principal Components Analysis on hydrochemical data, including natural fluorescence peaks and discharge. Plots of the variables (A) and statistical units (B). 
made up of samples having low concentrations of dissolved minerals, representing periods of high flows, which typically have higher contents of soil tracers In general, these presented lower concentrations of major chemical components and higher discharge rates, such as TOC, natural fluorescence and $\mathrm{NO}_{3}{ }^{-}$. Samples in the positive part of Axis II were collected after the significant flow event of November 2008, when the amounts of organic tracers, $\mathrm{NO}_{3}{ }^{-}$and $\mathrm{Cl}^{-}$from the soil were high (Fig. 5B). This was partly due to the flushing effect of the soil and the epikarst by the first heavy rainfall of the autumn. In contrast, the samples along the negative part of Axis II correspond to the other autumn and winter high-water events, when the
$\mathrm{NO}_{3}{ }^{-}$concentrations were low. This was mainly due to the washing effect of the soil and the epikarst by the first heavy rainfall of the autumn. Group 3 samples are tightly clustered in the negative parts of Axis I and close to zero on Axis II. These samples correspond to low flow periods, have higher contents of most chemical compounds and especially dissolved minerals, and lower amounts of the infiltration tracers. Group 2 samples are scattered between Groups 1 and 3, being approximately centred on the null values of the two axes. These samples occupy an intermediate position between Groups 1 and 3, and document an ongoing process of mineralization, following the end of a recharge event.

\section{CONCLUSION}

The joint use of conventional hydrogeochemical parameters and natural organic tracers in Yedra spring permit characterization of the karstification in the Sierra de las Cabras. The data reveal that the aquifer is highly karstified, typical of conduit flow systems, with rapid drainage and limited natural regulation. This karstification is developed in both the unsaturated and saturated zones, as evidenced by the response to precipitation events. Karst drainage favours the rapid infiltration and flow of rainwater, leading to increases in spring flow and decreases in most chemical concentrations, except for components leached from the soil whose concentrations increase. Hydroclimatic conditions govern the response, for example, $\mathrm{Cl}^{-}$contents of the spring increased after a heavy rain event that followed a protracted dry period, yet normally decreased during flood peaks, as did most other ions. Nitrate behaves similarly, but is influenced by the different biogeochemical kinetics in the soil. The char- acteristics deduced from the hydrochemical data mean that the fraction of water stored in this aquifer is not large and that Yedra spring is vulnerable to contamination, an aspect that should be taken into account for its adequate protection and management.

Finally, the TOC in Yedra spring is clearly associated with organic acids detected by spectrofluorescence, although this relationship depends on the organic matter character and the proportion of fluorescent organic matter. The strong linear relation observed between these substances and the TOC shows that the excitationemission fluorescence matrices can be used as another indicator of processes of leaching and rapid infiltration of water from the soil and epikarst. Thus, natural fluorescence could help evaluate and validate the vulnerability of karst aquifers to contamination. Consequently the investigation done in this work contributes to a sustainable management of the aquifer.

\section{ACKNOWLEDGMENTS}

This work is a contribution to projects CGL2005-05427 and CGL2008-06158 BTE of DGICYT, P06-RNM 2161 of Junta de Andalucía and IGCP 513 of UNESCO and to Research Group RNM-308 of Junta de Andalucía. The authors thank the constructive critical comments done by William B. White, Jiang Yongjun, Nico Goldscheider, and Bob Criss for their great efforts in improving the language. 


\section{REFERENCES}

Andrieux, C., 1978: Les enseignements apportés par la thermique dans le karst.- In: Colloque de Tarbes, Le karst: son originalité physique, son importance économique. Association des Géologues du SudOuest (AGSO), 48-63, France.

Appelo, C.A.J. \& D. Postma, 1996: Geochemistry, groundwater and pollution.- Balkema, pp. 536, Rotterdam.

Bakalowicz, M., 1977: Étude du degré d’organisation des écoulements souterrains dans les aquifères carbonatés par une méthode hydrogéochimique nouvelle.C.R. Acad. Sci. Paris, série D, 284, 2463-2466.

Bakalowicz, M., 1979: Contribution de la géochimie des eaux à la connaissance de l'aquifère karstique et de la karstification.- PhD Thesis. Sci. Nat., Univ. P. et M. Curie, París-VI, Géol. Dyn., pp. 269.

Baker, A., Barnes, W. L. \& P. L. Smart, 1997: Variations in the discharge and organic matter content of stalagmite drip waters in Lower Cave, Bristol.- Hydrological Processes, 11, 541-555.

Baker, A. \& D. Genty, 1999: Fluorescence wavelength and intensity variations of cave waters.- Journal of Hydrology, 217, 19-34.

Batiot, C., Emblanch, C. \& B. Blavoux, 2003a: Carbone organique total (COT) et Magnésium $\left(\mathrm{Mg}^{2+}\right)$ : Deux traceur complémentaires du temps de séjours dans l'aquifére karstique.- C R Geoscience, 335, 205214.

Batiot, C., Liñán, C., Andreo, B., Emblanch, C., Carrasco, F. \& B. Blavoux, 2003b: Use of TOC as tracer of diffuse infiltration in a dolomitic karst system: the Nerja Cave (Andalusia, southern Spain).- Geophysical Research Letters, 30, 22, 2179.

Blondel, T., 2008: Traçage spatial et temporel des eaux souterraines dans les hydrosystèmes karstiques par les matières organiques dissoutes.- $\mathrm{PhD}$ Thesis. Académie d'Aix-Marseille. Université d'Avignon et des Pays de Vaucluse, pp. 190.

Bonacci, O., 1993: Karst spring hydrographs as indicators of karst aquifers.- Journal of Hydrological Sciences, 38, 51-62

Cruz, Jr. F. W., Karmann, I., Magdaleno, G. B., Coichev, N. \& Jr. O. Viana, 2005: Influence of hydrological and climatic parameters on spatial-temporal variability of fluorescence intensity and DOC of karst percolation waters in the Santana Cave System, Southeastern Brazil.- Journal of Hydrology, 302, $1-12$.

Cumberland, A. C. \& A. Baker, 2007: The freshwater dissolved organic matter fluorescence-total organic carbon relationship.- Hydrological Processes, 21, 2093-2099.
Emblanch, C., Blavoux, B., Puig, J. M. \& J. Mudry, 1998: Dissolved organic carbon of infiltration within the autogenic karst hydrosystem.- Geophysical Research Letters, 25, 1459-1462.

Emblanch, C., Zuppi, G. M., Mudry, J., Blavoux, B. \& C. Batiot, 2003: Carbon 13 of TDIC to quantify the role of the unsaturated zone: the example of the Vaucluse karst systems (Southeastern France).- Journal of Hydrology, 279, 1-4, 262-274.

Genthon, P., Bataille, A., Fromant, A., D’Hulst, D. \& F. Bourges, 2005: Temperature as a marker for karst waters hydrodynamics. Inferences from 1 year recording at La Peyrére cave (Ariège, France).- Journal of Hydrology, 311, 157-171.

Goldscheider, N. \& D. Drew, 2007: Methods in Karst Hydrogeology.- Taylor \& Francis, pp. 262, London.

Hess, J.W. \& W.B. White, 1993: Groundwater geochemistry of the carbonate karst aquifer, southcentral Kentucky, USA.- Applied Geochemistry, 8, 189-204.

Karimi, H., Raeisi, E. \& M. Bakalowicz, 2005: Characterising the main karst aquifers of the Alvand basin, northwest of Zagros, Iran, by a hydrogeochemical approach.- Hydrogeology Journal, 13, 787-799.

Langmuir, D., 1997: Aqueous Environmental Geochemistry.- Prentice-Hall Inc., pp. 600, New Jersey.

Mangin, A., 1975: Contribution à l'étude hydrodynamique des aquifères karstiques.- Ann. Spéléol., 29, 3, 283-332, 4, 495-601, 30, 1, 21-124.

Marín, A. I., Andreo, B. \& M. Mudarra, 2007: Using the APLIS method to determine the spatial distribution of the recharge rate in the Alta Cadena karst aquifer (Southern Spain).- In: Ribeiro L. et al. (eds.) XXXV IAH Congress International Association of Hydrogeologists, Groundwater and Ecosystems, Proceedings, $17^{\text {th }}-21^{\text {st }}$ September 2007, Lisbon, Portugal. CDrom.

Mahler, B. J. \& B. D. Garner, 2009: Using Nitrate to Quantify Quick Flow in a Karst Aquifer.- Ground Water, 47, 3, 350-360.

Mudarra, M. \& B. Andreo, 2007: Sierra de las Cabras - Camarolos y San Jorge.- In: Diputación provincial de Málaga - IGME - UMA (eds.) Atlas Hidrogeológico de la Provincia de Málaga. Vol 2, pp. 113-118, Madrid.

Mudarra, M., Andreo, B. \& A. I. Marín, 2008: Consideraciones sobre la importancia de la zona saturada y no saturada en el funcionamiento hidrogeológico del acuífero carbonatado de la Alta Cadena (provincia de Málaga).- Geo-Temas, 10, 579-582. 
Mudry, J., 1987: Apport du tracage physico-chimique naturel à la connaissance hydrocinématique des aquifères carbonatés.- $\mathrm{PhD}$ Thesis. Université de Franche-Comté, Besançon, pp. 378.

Perrin, J., Jeannin, P.Y. \& F. Zwahlen, 2003: Implications of the spatial variability of infiltration-water chemistry for the investigation of a karst aquifer: a field study at Milandre test site, Swiss Jura.- Hydrogeology Journal, 11, 673-686.

Pronk, M., Goldscheider, N. \& J. Zopfi, 2006: Dynamics and interaction of organic carbon, turbidity and bacteria in a karst aquifer system.- Hydrogeology Journal, 14, 4, 473-484.

Pronk, M., Goldscheider, N., Zopfi, J. \& F. Zwahlen, 2009: Percolation and Particle Transport in the Unsaturated Zone of a Karst Aquifer.- Ground Water, 47, 3, 361-369.

Pulido Bosch, A. \& J. C. Cerón, 1991: Variaciones hidrogeoquímicas de periodicidad anual en surgencias kársticas. Ejemplo del manantial de la Yedra (Málaga).- Revista de la Sociedad Geológica de España, $4,1-2,51-59$.
Reisenhofer, E., Adami, G. \& P. Barbieri, 1998: Using chemical and physical parameters to define the quality of karstic freshwaters (Timavo river, NorthEastern Italy): A chemometric approach.- Water Research, 32, 4, 1193-1203.

Sanchez-Monedero, M.A., Roig, A., Pareded, C. \& M.P. Bernal, 2001: Nitrogen transformation during organic waste composting by the Rutgers system and its effect on $\mathrm{pH}, \mathrm{EC}$ and maturity of the composting mixtures.- Bioresource Technology, 78, 301-308.

Toran, L. \& B. White, 2005: Variation in nitrate and calcium as indicators of recharge pathways in Nolte spring, PA.- Environmental Geology, 48, 7, 854860. 